\title{
TRAFFIC ANALYSIS AND PAVEMENT TECHNOLOGY AS A TOOL FOR URBAN NOISE CONTROL
}

\author{
K. J. KOWALSKI ${ }^{1}$, A. J. BRZEZIŃSKI ${ }^{2}$, J. B. KRÓL ${ }^{3}$, \\ P. RADZISZEWSKI ${ }^{4}$, L. SZYMAŃSKI ${ }^{5}$
}

\begin{abstract}
Traffic related noise is currently considered as an environmental pollution. Paper presents results of multidirectional study attempting to serve urban traffic without the need to erect noise barriers interfering urban space. Initial concept of the road expansion included construction of $1000 \mathrm{~m}$ of noise barriers dividing city space. Improvement in the acoustic conditions after construction completion is possible due to the applied noise protection measures: vehicle speed limit, smooth of traffic flow, use of road pavement of reduced noise emission and the technical improvement of the tramway.
\end{abstract}

Keywords: traffic noise, traffic modelling and analysis, traffic forecast, road traffic organization, environment, asphalt pavement, tire/pavement interaction, technology

\section{INTRODUCTION}

In recent years in Poland and around the world public expectations concerning ecology and quality of life have increased. According to the EU "Noise Directive" (2002/49/EC), noise is classified as one of the pollutants that adversely affect the environment. Polish regulations (including Regulation of the Ministry of the Environment from June $14^{\text {th }} 2007$ "On permissible noise levels in the environment") initially imposed high restrictions, contributing to the construction of a large

\footnotetext{
${ }^{1}$ PhD. Eng., Assistant professor, Warsaw University of Technology, Faculty of Civil Engineering, office 540, al. Armii Ludowej 16, 00-637, Warsaw, Poland, k.kowalski@il.pw.edu.pl - corresponding author.

${ }^{2}$ PhD. Eng., Assistant professor, Warsaw University of Technology, Faculty of Civil Engineering, office 645, al. Armii Ludowej 16, 00-637, Warsaw, Poland, a.brzezinski@il.pw.edu.pl

${ }^{3} \mathrm{PhD}$. Eng., Assistant professor, Warsaw University of Technology, Faculty of Civil Engineering, office 540, al. Armii Ludowej 16, 00-637, Warsaw,Poland, j.krol@il.pw.edu.pl

${ }^{4}$ PhD. D.Sc., Professor, Warsaw University of Technology, Faculty of Civil Engineering, office 544, al. Armii Ludowej 16, 00-637, Warsaw, Poland, p.radziszewski@il.pw.edu.pl

${ }^{5}$ M.Sc Eng., Transeko sp.j., Poland, 1.szymanski@transeko.pl
} 
number of costly noise barriers. The requirements in this regard were relaxed ("Amending Regulation on the acceptable noise levels in the environment" dated October 1st 2012) as a result of protests at a substantial noise barriers interference in landscape, traffic safety risk (reduced visibility) and increased investment costs [1].

Road noise from vehicle traffic may be limited not only by the use of noise barriers [1]. The starting point in the search for mitigation solutions should be studying phenomena related to noise generation, enhancement and propagation. Noise barriers prevent noise propagation phenomena, but do not limit noise generation, associated, among other, with tires rolling on the pavement. Noise reduction at the source applies to technical solutions used in vehicles, how the vehicles operate, traffic management and road pavement surface layers.

An important factor causing traffic noise is type and condition of the pavement [2-5]. Asphalt mixtures are usually designed to ensure adequate load bearing capacity and comfort during service life, neglecting, however, their impact on traffic noise generation. Currently, it is possible to use asphalt mixtures that reduce rolling noise, such as porous asphalt (PA), some types of stone mastic asphalts (SMA) or other mixes of discontinuous aggregate gradation. Such solutions are commonly used in countries with moderate climate (e.g. the Netherlands, Belgium) [6].

Noise reduction can also be the result of measures related to the reduction of traffic in general (transfer of part of the journey on public transport and cycling), while reducing the bandwidth of the road section, limiting the traffic of selected types of vehicles (e.g. lorries) on a permanent basis at specific times of the day and appropriate traffic control (traffic flow management, speed reduction, fluidity of the improvement eliminating frequent car stops and accelerations) [7]. Furthermore it can be stated, that various strategies can be used to limit traffic-related noise, including barriers, technological solutions, traffic organization and legal regulations [8].

\section{PROBLEM STATEMENT, OBJECTIVES AND RESEARCH APPROACH}

The aim of the research presented in this paper was to evaluate the risk of acoustic climate deterioration during the day and night periods, due to road expansion project, involving construction of a second carriageway of Wołoska St. in Warsaw (Poland) and reconstruction of the existing carriageway as well as tram tracks modernization. An assessment has been carried out for three time horizons: current status, the year of construction completion (state after construction) and long term (year of 2030). 


\subsection{ROAD SECTION FEATURES}

Investigations were carried out in the area surrounding to the reconstructed arterial street Wołoska on a section of a length of approximately $700 \mathrm{~m}$ between Racławicka and Konstruktorska streets (Fig. 2). The project was located in the southern part of the central area of Warsaw (Mokotów district, Fig 1). The west side of the street is built-up mainly with single-family residential buildings (detached and terraced houses). On the east side there are a tall multi-family residential housing and one- and two-story commercial pavilions. In the vicinity of Woronicza street intersection multifamily housing and school buildings are located. Close to the intersection with Racławicka street, four-story office, commercial building and a hospital are located.

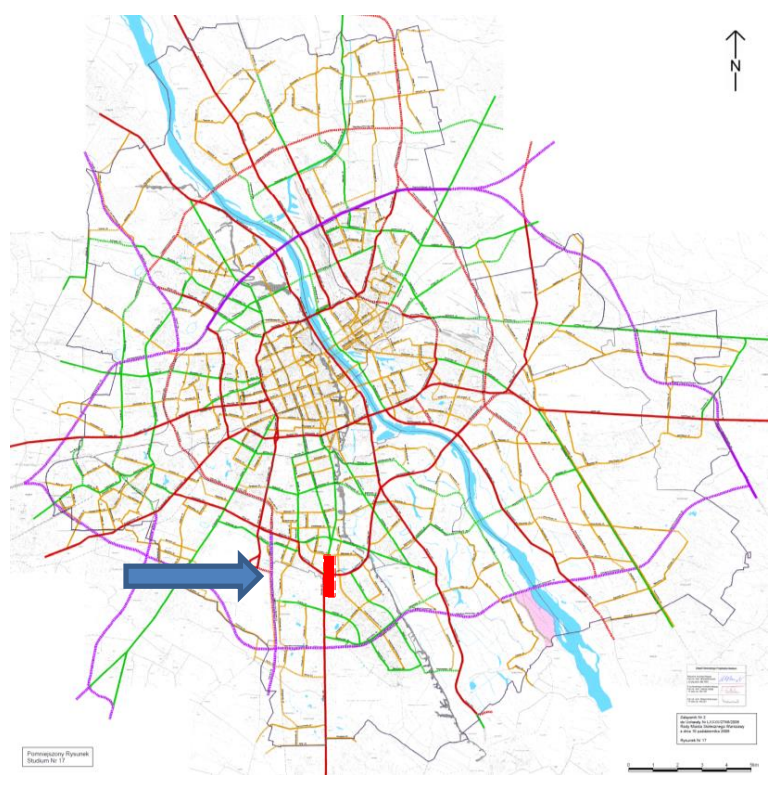

Fig. 1. Location of Wołoska Street reconstruction project on the background of the planned Warsaw road system.

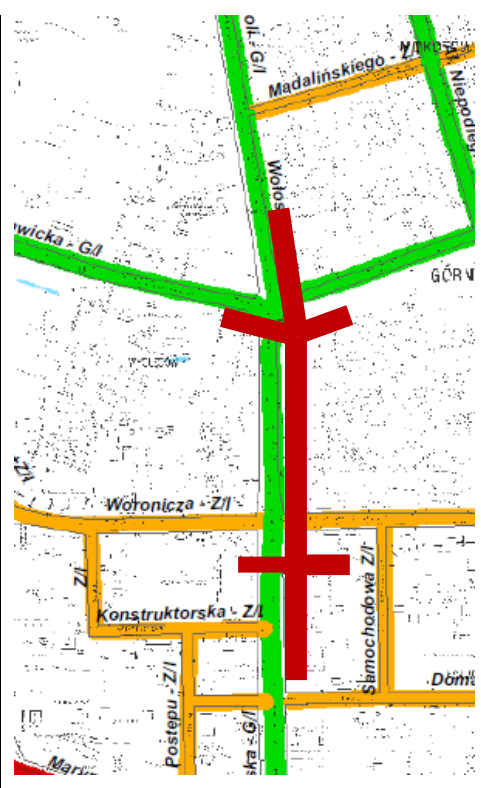

Fig. 2. Details of location of Wołoska Street reconstruction project.

It was identified that cars and motor bikes are the source of noise depending on:

- traffic volume,

- speed,

- pavement type and its condition,

- traffic structure. 
As well as trams on the track scheduled to be rebuilt with the noise volume depending on:

- type and technical condition of the rolling stock,

- frequency and speed of movement,

- construction and technical condition of the track.

The study revealed that the current state of acoustic conditions are fair, and noise excess reaches up to $2,5 \mathrm{~dB}$ in the daytime and to approx. $6 \mathrm{~dB}$ at night. Table 1 summarizes road traffic and Table 2 tram traffic volumes.

Table 1. Current road traffic volume.

\begin{tabular}{|c|c|c|c|c|c|}
\hline \multirow{2}{*}{ Street } & Section & \multicolumn{2}{|c|}{ Daytime } & \multicolumn{2}{c|}{ Night time } \\
\cline { 3 - 5 } & & LV & HV & LV & HV \\
\hline Wołoska & $\begin{array}{l}\text { Racławicka - Woronicza } \\
\text { (both directions together) }\end{array}$ & 22501 & 1314 & 1596 & 258 \\
\hline
\end{tabular}

LV - light vehicles, HV - heavy vehicles

Table 2. Current tram traffic volume.

\begin{tabular}{|c|c|c|c|}
\hline Street & Section & Daytime & Night time \\
\hline Wołoska & $\begin{array}{l}\text { Racławicka - Woronicza } \\
\text { (both directions together) }\end{array}$ & 579 & 81 \\
\hline
\end{tabular}

\subsection{METHODOLOGY OF THE ANALYSIS}

Considering alternatives to opt out noise barriers, the analysis takes into account multi-directional noise emission reduction measures, such as vehicles speed limit, increase of traffic smoothness, use of road pavement reducing noise emission and modernization of the tramway. It required carrying out detailed measurements of traffic, traffic forecasts, acoustic analysis and formulating proposals of solutions in terms of technology and materials that would reduce noise at source.

In order to perform analysis, a specially designed computer traffic model was developed that encompassed the entire city $[9,10]$. In area of Wołoska street the accuracy of the model was increased by calibration and validation process using measured traffic data on a section of Wołoska street between Racławicka and Woronicza street and at the intersection of Woronicza / Racławicka / Odyńca. Cross-street traffic volumes were measured during two days (Wednesday and Thursday) for twenty four hours, divided into categories of vehicles. Traffic volumes, types and directional structure of vehicles were recorded using MioVision SCOUT video image recording device. This 
method allowed for precise and long term traffic recording and automated reading of the traffic structure and volume.

For the purpose of traffic forecasting, the existing Warsaw traffic model was used, but adapted and tailored to the needs of the analysis taking into consideration results of traffic counts. Traffic model including public and individual transport is based on a numerical representation of the transport networks, reflecting the actual layout of both transport networks (road, and PT) as well as the traffic conditions. Transport network model consists of sections and nodal points, with operational parameters and coordinates locating these elements on the ground and public transport lines, also tram lines and stops. The territorial scope of the model includes Warsaw within and adjacent 46 municipalities that make up the Warsaw Metropolitan Area (Fig 3).

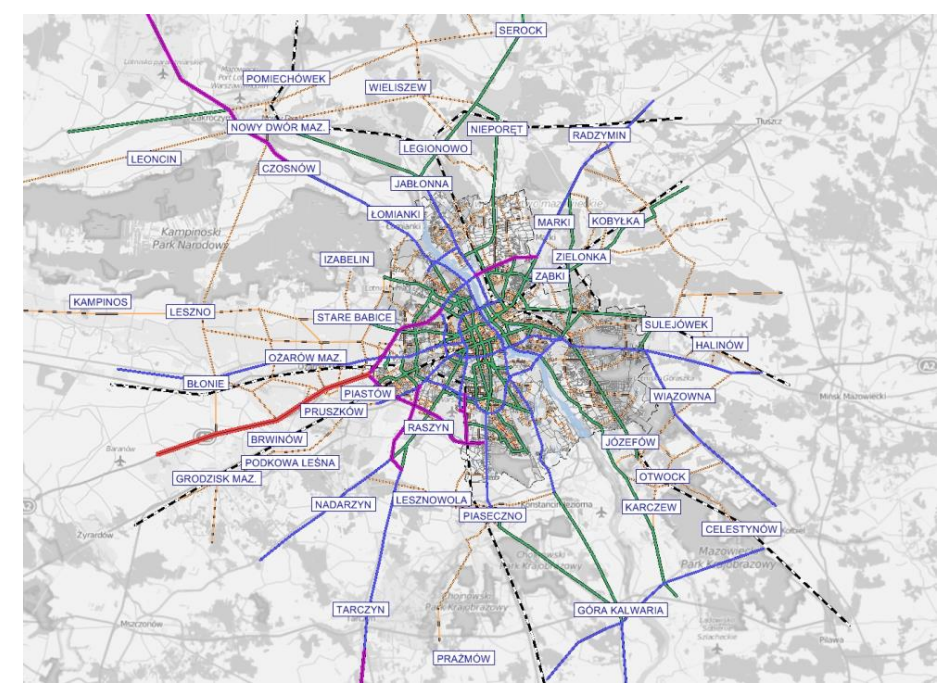

Fig. 3. The territorial scope of the traffic model (background: openstreetmap.org).

Model of current state forms a basis for forecasts taking into account the assumptions concerning: the planned changes of city road network, spatial development, demography and macroeconomic parameters (for example GDP increase, car ownership). Future traffic model was made for internal trips of people in the city as well as suburban, broken down into seven groups of motivation: homework, home-school, home-other, non-home (other-other), work-home, school-home, other-home.

Trips matrices were calculated for peak-hours, using a classic method for model building based on four stages:

- trips generation in traffic zones, broken down into trip motivations, 
- trips distribution between zones, broken down as above, calculated using gravity model (matrix-spatial distribution),

- modal split,

- traffic assignment.

Trips generation for all motivations was estimated taking into consideration daily mobility of the residents and the share of peak-hour for particular motivations. In the gravity model, as the resistance, the shortest travel time was assumed between a pair of zones resulting from individual and public transport journey times, taking into consideration congestion. The standard gravity model was used. It was described by the Eq. (2.1):

$$
T_{i j}=\frac{P_{i} A_{j} F_{i j} K_{i j}}{\sum_{j=1}^{n} A_{j} F_{i j} K_{i j}}
$$

where:

Tij - number of trips generated in zone „,i”, a finished in zone ,j”,

$\mathrm{Pi}$ - number of trips generated in zone ,i”,

$\mathrm{Aj}$ - numer of trips finished in zone , $\mathrm{j}$ ”,

Fij - space resisntance ratio (resistance function),

Kij - preference ratio taking into consideration deviations from the actual trip values in particular pair of zones.

With resistance function of the form as expressed with Eq. (2.2):

$$
F_{i j}=a * t_{i j}^{b} * e^{-\alpha * t_{i j}}
$$

where:

tij - travel time between zones ,i” and ,j”,

$a, b, \alpha$ - parameters defining the shape of the curve,

$\mathrm{e}-$ the base of the natural logarithm.

The modal split for the internal trips in motivation home-work-home and home-others-home, i.e. the determination which means of transport (individual or public), was calcultated using logit model, taking into account the level of motorization, duration of travel time by car during peak hour, duration of the trip, attractiveness of public transport, parking fees and parking potential. First the ratio was adopted of motorized people to non-motorized, travelling in each motvation. It was asumed that access to the car (also as a passenger) have $70-80 \%$ of the inhabitants of Warsaw. 
On this basis, the partial matrix of non-motorized people using public transport was derived. For the remaining group of people, the probability of travel by car or public transport was calcululated using the formulas Eq. (2.3 and 2.4):

$$
P_{P r T}=\frac{e^{U_{P r T}}}{e^{U_{P r T}}+e^{U_{P u T}}}
$$

$$
P_{P u T}=\frac{e^{U_{P u T}}}{e^{U_{P r T}}+e^{U_{P u T}}}
$$

where:

PPrt - probability of travel by car,

PPut - probability of travel by public transport,

UPrT - function describing character of the trip by car between pair of zones done,

UPuT - function describing character of the trip by public transport between pair of zones.

In order to define the nature of the travel by car between the pair of zones, the duration of the travel in peak hour, parking fees and the availability of parking spaces at the destination zone were taken into account. In order to define the nature of the travel using public transport the time of travel were taken into account, including the number (time) of interchanges, vehicle frequency, stops access times, and waiting times at the stops. The parameters of the modal split model were calibrated to the volumes of traffic in individual and public transport recorded on measurement screen points and the results of the household survey as well. For calculations VISUM computer system was used, based on a numerical models of the road network and urban development. Trip matrices were calculated for morning (Fig. 4) and afternoon peak hours. Within the research work, an alternative pavement structure was indicated that increases the noise protection level associated with the street reconstruction project. The aim was to find technological solutions limiting rolling noise emissions "at source", through the use of a non-standard material and technological solutions of surface course. For the analyzed area, surrounding the Wołoska street, on the basis of land development plan, acceptable noise levels were estimated. All-day car and tram noise measurements in four measuring locations were performed. These measurements were used to assess the current state of the acoustic environment and to calibrate the computation model. Because of the complex noise sources, the analysis uncertainty was estimated at approximately $\pm 3 \mathrm{~dB}$. 


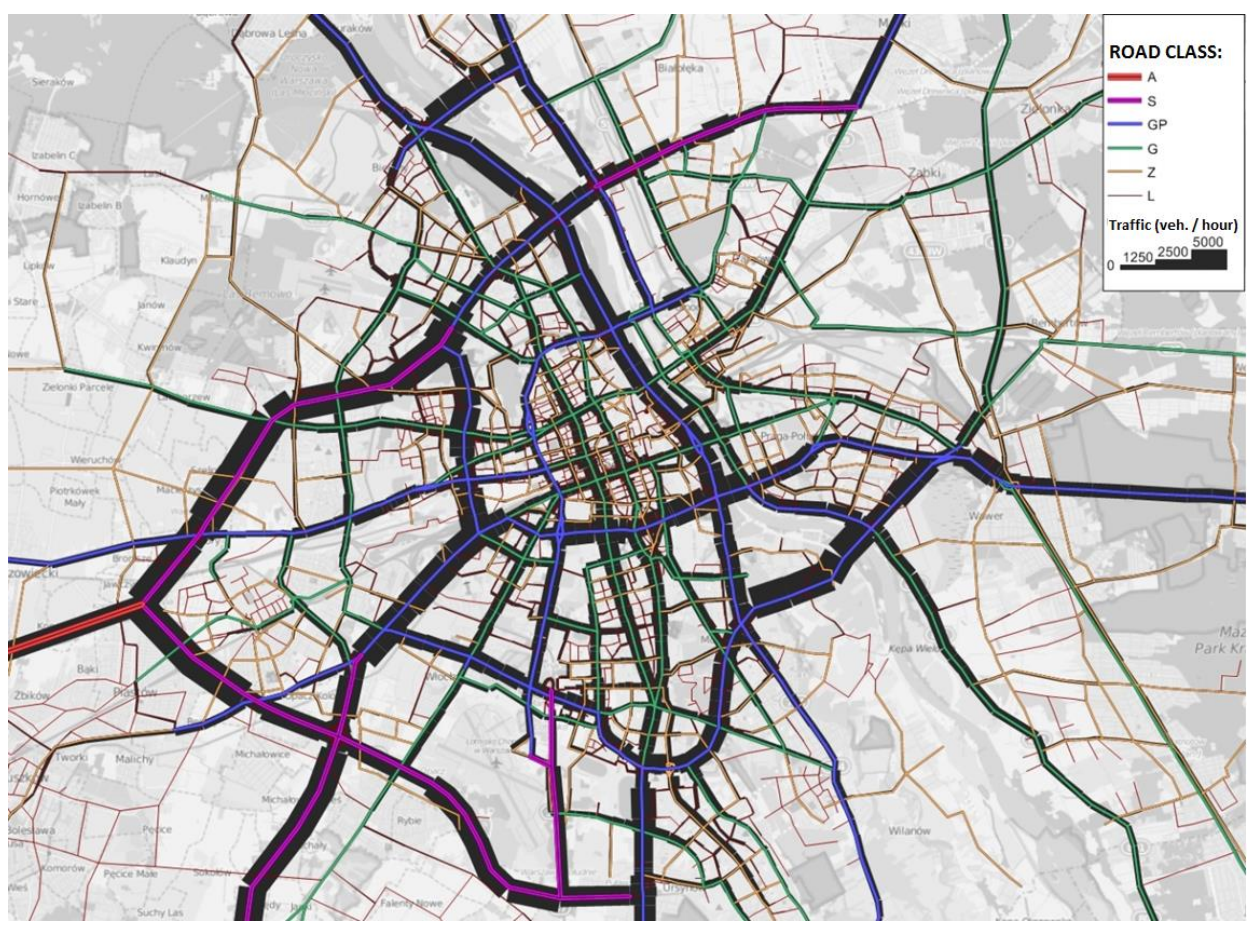

Fig. 4. An example of traffic model used in calculations - traffic assignment on road in morning peak hour (background: openstreetmap.org).

In addition to measurements at selected locations, the noise computations were performed in immission points located in front of the facades of all residential buildings, located in the first line of buildings. Assessment of the car and tram traffic noise impact in the surrounding areas of the planned project was carried out by establishing noise levels indicators LAeqD and LAeqN in the environment. In addition, the range of contour lines of equivalent sound level $\mathrm{A}$ in daytime and night time were set out. Calculations were performed using the software for acoustic calculations SoundPLAN 7.1, incorporating results from the aforementioned methods. The basis for the calculation was situational digital model of the planned project, which comprises catalogued buildings with its assigned height, the planned transport infrastructure (roadways, tracks) with its technical parameters and traffic volume forecast. 


\section{FACTORS AFFECTING NOISE ANALYSES}

\subsection{TRAFFIC VOLUME FORECAST}

Traffic forecasting model is directly linked with changes in land use of each of city area which directly affects the changes in the number of residents and jobs and consequently the volume of generated traffic. Based on the latest demographic estimations for Warsaw [11], it was assumed that the target number of residents of the city will reach approximately 2400000 . The traffic analysis assumes that in the year of construction completion, the population within the city limits would be 2020000 inhabitants and by the year of 2030, 2287000 inhabitants. The assumptions take into account population growth in the group of permanently and temporary registered persons (employees, students, etc.). Based on the forecasts, it was found that the total traffic per 16 hour of the day time will be the $93 \%$ of the average daily traffic. The heavy vehicles traffic will produce $3 \%$ of the total traffic volume during daytime and $9 \%$ of the total traffic at night.

Noise analysis was performed for the current state and for two time horizons:

- the year of the construction completion and service commencement,

- after 15 years of service - year 2030.

The forecasted traffic volumes of light and heavy vehicles used in the noise calculations are shown in Tables 3 and 4, respectively, for the year of construction completion and year 2030, broken down by time of day (6-22) and night (22-6). Constant tram traffic was assumed.

Table 3. Car traffic forecast in the year of construction completion.

\begin{tabular}{|c|c|c|c|c|c|}
\hline \multirow{2}{*}{ Street } & \multirow{2}{*}{ Section } & \multicolumn{2}{|c|}{ Daytime } & \multicolumn{2}{c|}{ Night time } \\
\cline { 3 - 6 } & & EN & PC & EN & PC \\
\hline Wołoska & Racławicka - Rudy & 36115 & 1032 & 2562 & 280 \\
\hline Wołoska & Rudy - Woronicza & 39662 & 1063 & 2813 & 290 \\
\hline
\end{tabular}

Table 4. Car traffic forecast in 2030.

\begin{tabular}{|c|c|c|c|c|c|}
\hline \multirow{2}{*}{ Street } & \multirow{2}{*}{ Section } & \multicolumn{2}{|c|}{ Daytime } & \multicolumn{2}{c|}{ Night time } \\
\cline { 3 - 6 } & & EN & PC & EN & PC \\
\hline Wołoska & Racławicka - Rudy & 40135 & 1067 & 2847 & 292 \\
\hline Wołoska & Rudy - Woronicza & 38716 & 1055 & 2746 & 288 \\
\hline
\end{tabular}




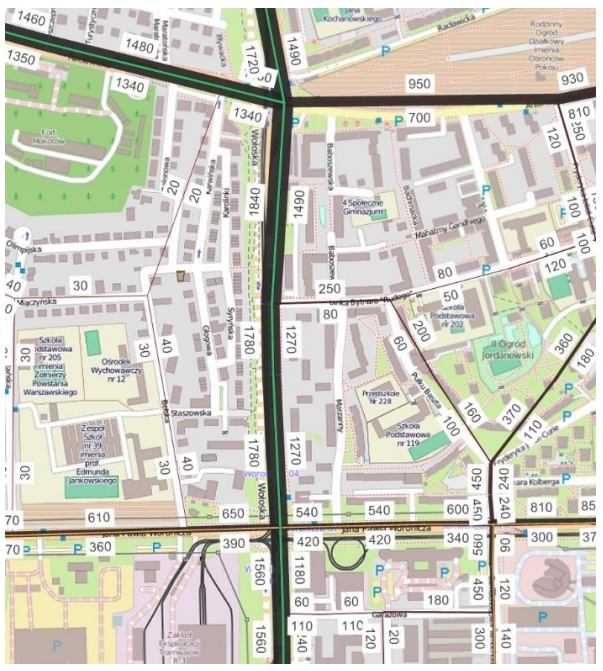

Fig. 5. Traffic forecast for 2030 - morning peak hour (background: openstreetmap.org).

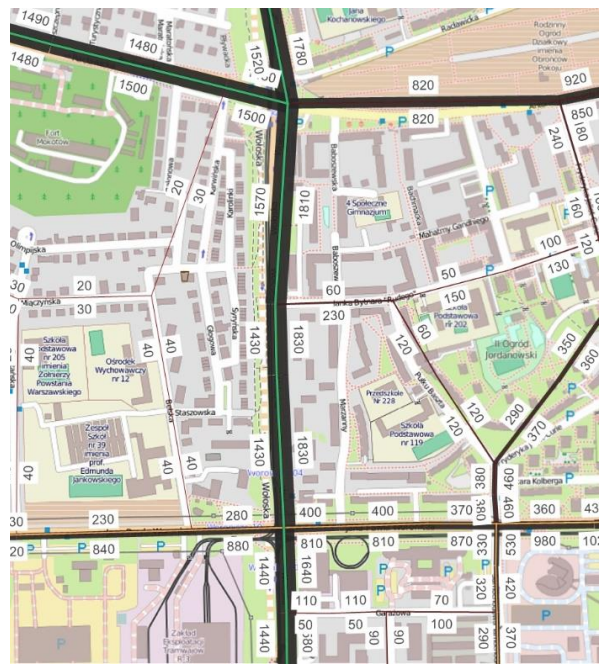

Fig. 6. Traffic forecast for 2030 - afternoon peak hour (background: openstreetmap.org).

\subsection{VEHICLE SPEED AND TRAFFIC FLOW}

Vehicle speed limits adopted in the noise emission calculation are shown in Table 5. It was assumed that the traffic in the current state is pulsing and during the forecasted period - uniform (as a result of changes in the traffic organization leading to an increase of traffic flow smoothness). Close to intersections, for noise calculations the following assumptions were made: uneven traffic with acceleration - over a distance of $150 \mathrm{~m}$ from the intersection and uneven traffic with braking - over a distance of $100 \mathrm{~m}$ from the intersection.

Table 5. The vehicle speeds used in the calculation of noise emissions.

\begin{tabular}{|c|c|c|}
\hline Time of day & $\begin{array}{c}\text { Light vehicles } \\
{[\mathrm{km} / \mathrm{h}]}\end{array}$ & $\begin{array}{c}\text { Heavy vehicles } \\
{[\mathrm{km} / \mathrm{h}]}\end{array}$ \\
\hline \multicolumn{3}{|c|}{ current state } \\
\hline day & 58 & 54 \\
\hline night & 65 & 61 \\
\hline \multicolumn{3}{|c|}{ state after construction completion } \\
\hline day & 50 & 50 \\
\hline night & 50 & 50 \\
\hline
\end{tabular}

On the basis of the measurements, the average speed of trams in both directions was assumed at the level of $37 \mathrm{~km} / \mathrm{h}$. For the purposes of the forecasting calculation the tram speed was increased to 40 $\mathrm{km} / \mathrm{h}$ in both directions. 


\subsection{MATERIAL AND TECHNOLOGICAL SOLUTIONS DECREASING NOISE LEVEL}

\section{AT SOURCE}

Mineral-asphalt mixes lowering rolling noise include porous asphalt (PA), certain types of stone mastic asphalt (SMA) or other asphalt mixes of discontinuous grain size, such as BBTM of void content of $8-12 \%$. Effectiveness analysis of material and technological solutions in rolling noise reduction was carried out by comparing domestic and foreign studies compared to the SMA 11 reference solution used in Poland as a standard [1,12,13] supported in the analyzes by the [14]. Detailed information for comparative analysis are as follows:

- the proposed technology of the wearing course of BBTM 8B:

- AAV4 CPX method (truck tire) at $50 \mathrm{~km} / \mathrm{h}: 87,5-89,5 \mathrm{~dB}(\mathrm{~A})$,

○ CPX method SRTT (passenger vehicle tire) at $50 \mathrm{~km} / \mathrm{h}: 86,5-88,5 \mathrm{~dB}$ (A),

○ pavement noise effectiveness measurement made after tearing off asphalt binder film from the upper surface of the particle aggregates in contact with a car tire,

- SMA 11 reference pavement:

- AAV4 CPX method (truck tire) at $50 \mathrm{~km} / \mathrm{h}: 91,0-93,0 \mathrm{~dB}(\mathrm{~A})$,

- CPX method SRTT (passenger vehicle tire) at $50 \mathrm{~km} / \mathrm{h}: 91,0-93,0 \mathrm{~dB}(\mathrm{~A})$,

- the estimated average improvement:

- AAV4 CPX method (truck tire) at $50 \mathrm{~km} / \mathrm{h}: 3,5 \mathrm{~dB}$,

- CPX method SRTT (passenger vehicle tire) at $50 \mathrm{~km} / \mathrm{h}: 4,5 \mathrm{~dB}$.

The data indicate that the proposed solution contributes to reducing of the rolling noise by approximately $4 \mathrm{~dB}$ and is much more favorable as compared to the theoretically possible to obtain noise reduction of $0,8-1,0 \mathrm{~dB}$ once SMA 8 mixture would be used. It should be noted that the decibels indicate noise levels set on a logarithmic scale, therefore, a reduction of $4 \mathrm{~dB}$ means almost halved perceived noise level recorded by the recipient. It should also be stated that the doubling of traffic volume increases noise by about $3 \mathrm{~dB}$.

\subsection{NOISE MEASUREMENTS}

In the analysis a calculation method was applied recommended by Directive 2002/49/EC of the European Parliament and of the Council of 25 June 2002 relating to the assessment and management of environmental noise. The calculations were made using the SoundPLAN 7.1 software, in which the above mentioned methods are implemented. The basis for the calculations was the digital model of the planned investment, containing inventory of buildings along the street 
with their height, the transport system together with its technical parameters and traffic forecasts. Calculations took into account the noise absorption by air for air temperature $10^{\circ} \mathrm{C}$ and $70 \%$ humidity. Calculations were calibrated by noise monitoring results. The calculation of noise propagation in the environment was performed using the French calculation method "NMPBRoutes-96 (SETRA-CERTU-LCPC-CSTB)" referred in "Arrêté du 5 mai 1995 relatif au bruit des infrastructures routières, Journal Officiel du 10 mai 1995, article 6. and the French standard "XPS 31-133". This method is based on the model of the spread of sound in the environment set out in PN ISO 9613-2 "Acoustics. Sound attenuation during propagation in space. ", while the input data regarding emissions are determined in accordance with the" Guide du bruit des transports terrestres, fascicule prévision des niveaux sonores, CETUR 1980 ".

Noise recorded prior construction for passenger vehicles, measured and averaged over 24-hours, was $69,3 \mathrm{~dB}$ (equivalent A-sound level in the range of one hour). The calculated equivalent sound level was $71,6 \mathrm{~dB}$, according to SoundPLAN 7.1 software. For trams the waveforms recorded during the measurement allowed to determine sound A level including division of the direction of movement. The average level of exposure to noise from tram traffic is in the direction of Woronicza $\mathrm{L} A E=83,8 \mathrm{~dB}$, and the Odyńca $\mathrm{L} \mathrm{AE}=82,9 \mathrm{~dB}$. Calculated using SoundPLAN 7.1 software, equivalent $\mathrm{A}$-sound level at a speed of $37 \mathrm{~km}$ tram / $\mathrm{h}$ was in the direction Woronicza $\mathrm{L} \mathrm{AE}=76,6$ $\mathrm{dB}$ and toward Odyńca $\mathrm{L} \mathrm{AE}=75,9 \mathrm{~dB}$. In both cases, the difference between the measured and calculated values was adopted as a calibration amendment to car traffic noise calculations $(-2,3 \mathrm{~dB}$ for car traffic, $+7,1 \mathrm{~dB}$ for tram traffic).

\section{MULTIDIRECTIONAL ANALYSIS OF TRAFFIC NOISE MITIGATION}

In accordance to the adopted assumptions, the use of alternative solution to noise barriers brought positive results, confirmed by using SoundPLAN 7.1 software. The proposed multidirectional activities made it possible to reduce traffic noise emission. The following solutions of noise reduction were included:

- car speed limit reduction to $50 \mathrm{~km} / \mathrm{h}$ during the day and night,

- traffic lights coordination, which in combination with the speed control on a section between street intersections will eliminate speeding,

- pavement surface with reduced noise emission, the effectiveness of 4,5 $\mathrm{dB}$ for passenger vehicles and 3,5 $\mathrm{dB}$ for heavy duty vehicles. 
Furthermore, in addition to planned tramway modernization, it was recommended to decrease permissible tram speed limit to $40 \mathrm{~km} / \mathrm{h}$ in both directions, in accordance to the value adopted in this analysis.

In relation to official Polish requirements for protection against noise in the pre-construction phase and forecast periods of time, the exceedances of car traffic noise values were calculated (Table 6). In the case of tram noise, no exceedances of limit values were found neither in current state nor in forecast period.

Table 6. The exceedance of the car noise limit value.

\begin{tabular}{|c|c|c|c|c|}
\hline \multirow{2}{*}{ Time } & \multicolumn{2}{|c|}{$\begin{array}{c}\text { The exceedance of the car noise limit } \\
\text { value }\end{array}$} & $\begin{array}{c}\text { The exceedance of the cumulative noise limit } \\
\text { value }\end{array}$ \\
\cline { 2 - 5 } & Day time & Night time & Day time & Night time \\
\hline $\begin{array}{c}\text { Current state } \\
\text { State after construction } \\
\text { completion }\end{array}$ & $2,0 \mathrm{~dB}$ & $5,3 \mathrm{~dB}$ & $2,5 \mathrm{~dB}$ & $2,5 \mathrm{~dB}$ \\
\hline Year 2030 & $1,3 \mathrm{~dB}$ & $1,8 \mathrm{~dB}$ & $2,9 \mathrm{~dB}$ & $1,7 \mathrm{~dB}$ \\
\hline
\end{tabular}

The calculation results presented in Table 6 indicate that car traffic is the dominant noise source after the construction completion as well as during the current state. Expected decreased exceedance values of acceptable levels after construction completion mean that at night the acoustic conditions will be improved as compared to the current state. Eventually, improvement will gradually take place up to year 2030.

The noise protection solutions have been included in the assessment of the acoustic climate for construction options in the year of construction completion and in the time horizon of year 2030 . Noise ranges graphically shown on Fig. 7 indicate that in the year of target forecast (year 2030) of the abovementioned solutions, it will be sufficient to provide acoustic comfort in the adjacent noise protected buildings. 


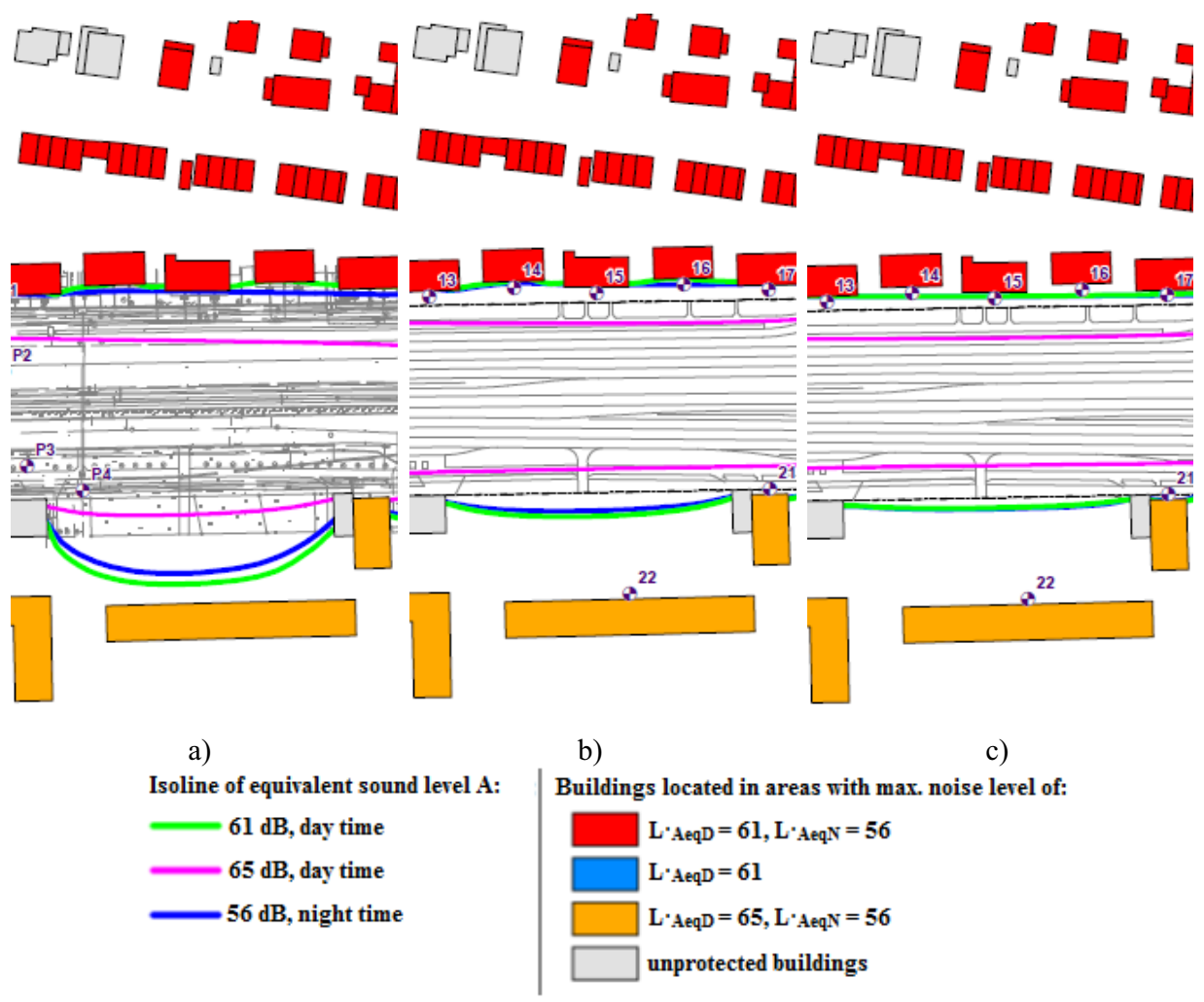

Fig. 7. The calculation results of acoustic effects with sound level contour lines in the vicinity of road: a) before the construction commencement, b) after construction completion c) year 2030.

On the basis of the analyses, it was found that in the daytime and nighttime there will occur slight exceedances of limit values, somewhat larger in the state after construction completion (less than $3 \mathrm{~dB}$ ), and less than $2 \mathrm{~dB}$ in 2030 . Those transgressions are on the level of uncertainty level of calculation method approximately $2 \div 3 \mathrm{~dB}$ ).

\section{CONCLUSIONS}

Technical and technology development allows the use of modern material and traffic organization solutions that reduce road traffic noise. It was found that the previous assumptions concerning SMA 8 wearing course will not guarantee a sufficient traffic noise reduction that is generated on the tire-pavement interaction and results in the necessity of noise barriers erection. In the light of the above, accordingly, in place of SMA 8 the use of BBTM 8B asphalt mixture with rubber-asphalt 
binder was proposed. Throughout the analyzed section, speed limited to $50 \mathrm{~km} / \mathrm{h}$ (day and night) was established. To ensure the movement of vehicles at such speed, the use of speed camera together with coordination of traffic lights was recommended.

For the purposes of calculations, in reference to the current status, a noise reduction emission of individual vehicles at $1 \mathrm{~dB}$ was assumed, as a result of technological progress of automotive industry, in accordance with the assumptions of European Commission on reducing the permissible emission standards for vehicles and the increase in the quality of the national vehicle fleet. The replacement of the rolling stock of the public transportation shall also provide effects on the noise reduction.

On the basis of acoustic calculations measured in immission points located in front of the facade of all residential buildings located in the first line and designated range of contour lines of equivalent sound level $\mathrm{A}$ in daytime and night time, it was found that in the current conditions the acoustic climate is poor because the values exceed limit levels by $2.5 \mathrm{~dB}$ in the daytime and approximately 6 $\mathrm{dB}$ at night.

It was estimated that in year 2030 the exceedance of the noise limit levels will reach $1,8 \mathrm{~dB}$ in the daytime and $1,7 \mathrm{~dB}$ at night and be comparable to the forecast uncertainty rate. It was also found that, regardless of the analyzed period, the car traffic is responsible for exceedance of noise limits. Improvement in the acoustic conditions after construction completion will be possible due to the applied noise protection measures: car speed limit, smooth traffic flow of cars, use of road pavement of reduced noise emission and the technical improvement of the tramway.

Due to negligible excess of acceptable noise level with respect to uncertainty of forecasts, no other measures were proposed. This means that as a result of the calculations it will be possible to abandon the initial assumption concerning the use of noise barriers in the analyzed section of the city road.

\section{DiSCLAIMER AND ACKNOWLEDGEMENTS}

Work presented in this paper was supported by The Warsaw Urban Road Investment Management Office. The authors wish to thank all colleagues from the Institute of Roads and Bridges of Warsaw University of Technology for collaboration in this research project. 


\section{REFERENCES}

1. K.J. Kowalski, P. Radziszewski, W. Bańkowski, K. Otkałło, „Tire/pavement noise on the prototype pavement sections" [in Polish]. Metody ochrony środowiska przed hałasem. Teoria i praktyka, Zakopane 2013, pp. $145-157$.

2. W. Gardziejczyk, "Influence o road pavements construction technology and texture on vehicle noise" [in Polish], Białystok 2005.

3. W. Bańkowski, "Quite pavements around the world" [in Polish].Materiały Budowlane, nr 11, 2011, pp. 51-53.

4. J. Piłat, P. Radziszewski, Asphalt pavements [in Polish]. WKiŁ, Warszawa 2010.

5. K.J. Kowalski, T. Dare, R.S. McDaniel, J. Olek, R. Bernhard, "Research on a laboratory technique for tirepavement noise assessment of asphalt mixes". Archives of Civil Engineering, vol. LIX, is. 4, 2013, pp. 561-577.

6. K.J. Kowalski, R.S. McDaniel, A. Shah, J. Olek, „Long Term Monitoring of the Noise and Frictional Properties of PFC, SMA and DGA Pavements", Transportation Research Record, vol. 2127, 12-19, 2009.

7. A. Brzeziński, A. Ciołkosz-Styk, M. Gruziel, P. Kwiatkowski: Intelligent transportation systems as a chance for cities sustainable development [in Polish]. "Kształtowanie współczesnej przestrzeni miejskiej”. Wydawnictwa Uniwersytetu Warszawskiego, 2014 pp. 587-599.

8. M. Tracz, J. Bohatkiewicz, ,Selected problems of noise protection - suggestions of changes in law regulations and strategies" [in Polish], TransNoise, Zakopane, 2012.

9. A. Brzeziński, P. Włodarek: „Problem stosowania uogólnionego modelu ruchu w procesie planowania i projektowania regionalnej i lokalnej sieci drogowej" [in Polish]. General Directorate of National Roads and Motorways Conference: Analiza i modelowanie ruchu na sieci drogowej. Politechnika Warszawska, 2010.

10. A. Brzeziński: „Znaczenie modelowania ruchu w analizach sieci drogowej” [in Polish]. General Directorate of National Roads and Motorways Conference: Analiza i modelowanie ruchu na sieci drogowej. General Directorate of National Roads and Motorways, 2010.

11. P. Śleszyński, „Aktualne i spodziewane tendencje demograficzne w rozwoju Obszaru Metropolitarnego Warszawy oraz Struktura i rozmieszczenie miejsc zamieszkania, pracy i edukacji w Warszawie według rejonów komunikacyjnych" [in Polish]. IGiPZ PAN, 2010.

12. P. Mioduszewski, "Road nosiness in Poland and in another European Union countries" [in Polish]. Metody ochrony środowiska przed hałasem. Teoria i praktyka, Zakopane 2013, pp. 159-173

13. I. Ruttmar, "Pavement technologies for quite pavements - comparison. Wymagania techniczne w Polsce i w Niemczech" [in Polish], Proceedings of Transnoise Conference, Zakopane 2013

14. M. Książek, P. Nowak, S. Kivrak, J. Rosłon, L. Ustinovichius, "Computer-aided decision-making in construction project development", Journal of Civil Engineering and Management, vol. 21, is. 2, 2015, pp. 248-259. 


\section{LIST OF FIGURES AND TABLES}

Fig. 1. Location of Wołoska Street reconstruction project on the background of the planned Warsaw road system.

Rys. 1. Lokalizacja przebudowywanej ul. Wołoskiej na planach układu komunikacyjnego Warszawy

Fig. 2. Details of location of Wołoska Street reconstruction project.

Rys. 2. Szczegółowa lokalizacja przebudowywanej ul. Wołoskiej.

Fig. 3. The territorial scope of the traffic model (background: openstreetmap.org)

Rys. 3. Zakres terytorialny modelu ruchu (podkład: openstreetmap.org)

Fig. 4. An example of traffic model used in calculations - traffic assignment on road in morning peak hour (background: openstreetmap.org).

Rys. 4. Przykład modelu ruchu zastosowanego w obliczeniach-natężenie pojazdów w rannym szczycie ruchu (podkład: openstreetmap.org)

Fig. 5. Traffic forecast for 2030 - morning peak hour (background: openstreetmap.org).

Rys. 5. Przewidywany ruch w roku 2030-natężenie pojazdów w rannym szczycie ruchu (podkład: openstreetmap.org)

Fig. 6. Traffic forecast for 2030 - afternoon peak hour (background: openstreetmap.org).

Rys. 6. Przewidywany ruch w roku 2030-natężenie pojazdów w popołudniowym szczycie ruchu (podkład: openstreetmap.org)

Fig. 7. The calculation results of acoustic effects with sound level contour lines in the vicinity of road: a) before the construction commencement, b) after construction completion c) year 2030.

Rys. 7. Wyniki obliczeniowe skutków akustycznych zastosowanych rozwiązań: a) przed realizacją przebudowy, b) po ukończeniu inwestycji, c) w roku 2030.

Tab. 1. Current road traffic volume.

Tab.1. Obecny poziom ruchu pojazdów samochodowych.

Tab.2. Current tram traffic volume.

Tab.2. Obecny poziom ruchu tramwajów.

Tab.3. Car traffic forecast in the year of construction completion.

Tab.3. Przewidywany ruch pojazdów w roku realizacji inwestycji.

Tab.4. Car traffic forecast in 2030.

Tab.4. Przewidywany ruch pojazdów w roku 2030.

Tab.5. The vehicle speeds used in the calculation of noise emissions.

Tab.5. Prędkość pojazdów przyjęta do obliczeń hałasu.

Tab.6. The exceedance of the car noise limit value.

Tab.6. Przekroczenia dopuszczalnego poziomu hałasu. 


\title{
ANALIZA RUCHU I TECHNOLOGIA NAWIERZCHNI JAKO NARZĘDZIE UMOŻLIWIAJĄCE OGRANICZENIE HALASU DROGOWEGO
}

\author{
Slowa kluczowe: hałas komunikacyjny, analiza ruchu, organizacja ruchu, środowisko, nawierzchnia asfaltowa, interakcja na \\ styku opona/nawierzchnia, technologia
}

\section{STRESZCZENIE}

Budowa ciągów komunikacyjnych na terenie miejskim, w tym jezdni samochodowych i torowisk tramwajowych, związana jest z koniecznością spełnienia wielu dodatkowych wymagań związanych z bezpieczeństwem, organizacją ruchu pojazdów i wymaganiami ochrony środowiska. W ostatnich latach w Polsce jak i na całym świecie wzrosły oczekiwania społeczne dotyczące hałasu komunikacyjnego. Zgodnie z tzw. „dyrektywą hałasową” UE (2002/49/EC) hałas klasyfikuje się jako jedno z zanieczyszczeń negatywnie wpływających na środowisko. W Polsce przepisy (m.in. rozporządzenie Ministra Środowiska z 14 czerwca 2007 r. „W sprawie dopuszczalnych poziomów hałasu w środowisku") początkowo nałożyły wysokie obostrzenia, przyczyniając się do budowy dużej liczby kosztownych ekranów akustycznych. Następnie wymagania w tym względzie złagodzono (,Zmieniające rozporządzenie w sprawie dopuszczalnych poziomów hałasu w środowisku” z 1 października 2012 r.) na skutek protestów związanych ze znaczną ingerencją ekranów w krajobraz, ryzykiem zagrożenia bezpieczeństwa ruchu (ograniczanie widoczności) oraz podwyższaniem kosztów inwestycyjnych.

Hałas drogowy pochodzący od ruchu samochodowego może być ograniczany nie tylko dzięki stosowaniu ekranów akustycznych. Punktem wyjścia w poszukiwaniu rozwiązań ograniczających hałas komunikacyjny i powszechne stosowanie ekranów akustycznych powinny być badania dotyczące rozwiązań technicznych pojazdów, sposobu ich eksploatacji, organizacji ruchu i nowych rozwiązań materiałowo-technologicznych w zakresie nawierzchni drogowych. Istotnym czynnikiem wywołującym hałas związany z ruchem samochodowym jest rodzaj i stan nawierzchni. Mieszanki mineralno-asfaltowe są zwykle dobierane w celu zapewnienia odpowiedniej nośności konstrukcji i komfortu użytkowania $\mathrm{w}$ okresie eksploatacji, z pominięciem przy doborze składu mieszanki wpływu na hałas związany z ruchem pojazdów. Tymczasem możliwe jest stosowanie mieszanek mineralno-asfaltowych obniżających hałas toczenia, takich jak: asfalt porowaty, niektóre rodzaje mastyksów grysowych SMA czy też inne mieszanki o nieciągłym uziarnieniu. Najbardziej efektywną technologią umożliwiającą budowę nawierzchni obniżającej hałas toczenia jest technologia asfaltu porowatego, powszechnie stosowana w krajach o klimacie umiarkowanym (np. Holandia, Belgia). Ze względu na szczególne warunki klimatyczne w Polsce, typowe rozwiązanie technologiczne asfaltu porowatego nie jest obecnie zalecane do powszechnego stosowania.

Ograniczenie hałasu może być także wynikiem działań związanych z ograniczaniem ruchu samochodowego (przeniesienie części podróży na transport zbiorowy i ruch rowerowy) przy jednoczesnym zmniejszeniu przepustowości przekroju drogi, ograniczaniem ruchu wybranych typów pojazdów (np. samochodów ciężarowych) na stałe lub w określonych porach dnia, czy też odpowiednim sterowaniu ruchem (zarządzanie dopływami ruchu, ograniczanie prędkości ruchu, utrzymywanie płynności ruchu z eliminowaniem częstego zatrzymywania i rozpędzania samochodów).

Władze Warszawy podjęły działania w celu usprawnienia ruchu komunikacyjnego na jednej z głównych ulic łączącej centrum miasta z jego południową częścią. Przeprowadzone wstępne symulacje wykazały, że planowana rozbudowa układu komunikacyjnego w tej części miasta spowoduje wzrost natężenia ruchu pojazdów, a także potencjalny konflikt 
$\mathrm{z}$ regulacjami prawnymi w zakresie dopuszczalnego natężenia hałasu w miejscu zabudowy jednorodzinnej oraz w obszarze specjalnej ochrony (szpitala).

W artykule przedstawiono wyniki analiz dotyczących opracowania wielokierunkowego rozwiązania, które pozwoli na modernizację ciągu komunikacyjnego umożliwiającą wzrost natężenia ruchu pojazdów bez konieczności budowy ekranów akustycznych ingerujących w przestrzeń miejską.

Początkowe założenia związane z inwestycją zakładały wykonanie ekranów akustycznych o długości około $1000 \mathrm{~m}$, dzielących zabudowę miejską. Na podstawie wykonanych analiz ruchu oraz modelowania zaproponowano rozwiązania ograniczające hałas drogowy poprzez zastosowanie innowacyjnej technologii górnej warstwy nawierzchni drogowej oraz działania z zakresu inżynierii ruchu drogowego. Zaproponowano zastosowanie nowego rozwiązania materiałowotechnologicznego dotyczącego mieszanki mineralno-asfaltowej o uziarnieniu otwartym i lepiszczu gumowo-asfaltowym charakteryzującej się obniżonym poziomem hałasu toczenia emitowanym na styku opona/nawierzchnia. W zakresie inżynierii ruchu drogowego proponowane rozwiązanie dotyczy poprawy przepustowości ruchu, ograniczenia ruchu pojazdów ciężkich oraz ograniczenia prędkości ruchu pojazdów. Poprawa warunków akustycznych po realizacji inwestycji będzie możliwa również ze względu na modernizację torowiska tramwajowego.

Zastosowane wielokierunkowe rozwiązania stanowiły podstawę do wykonania modelu ruchu, analizy modelu rozchodzenia się hałasu i zastosowania rozwiązań „cichej” nawierzchni drogowej. Rozwiązania materiałowotechnologiczne i organizacja ruchu pozwoliły na zbudowanie modelu akustycznego 3D. Przedstawione rozwiązania przeciwhałasowe zostały uwzględnione w ocenie stanu klimatu akustycznego dla wariantów inwestycyjnych w roku ukończenia inwestycji i w perspektywie horyzontu czasowego roku 2030.

$\mathrm{Na}$ podstawie wykonanych analiz stwierdzono, że wprowadzone rozwiązania materiałowo-technologiczne oraz dotyczące inżynierii ruchu będą wystarczające do zapewnienia komfortu akustycznego w przylegającej zabudowie chronionej akustycznie. Zaproponowane wielokierunkowe działania stworzą możliwość obniżenia emisji hałasu komunikacyjnego co jest alternatywą dla stosowania ekranów przeciwhałasowych. 
